\title{
Effect of Precursor Deficiency Induced Ca/P Ratio on Antibacterial and Osteoblast Adhesion Properties of Ag-Incorporated Hydroxyapatite: Reducing Ag Toxicity
}

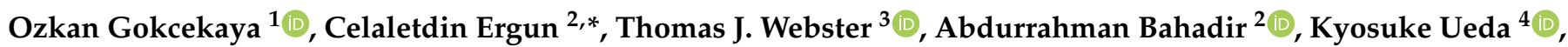 \\ Takayuki Narushima ${ }^{4}$ (D) and Takayoshi Nakano ${ }^{1} \mathbb{D}$ \\ 1 Division of Materials and Manufacturing Science, Osaka University, Suita 565-0871, Japan; \\ ozkan@mat.eng.osaka-u.ac.jp (O.G.); nakano@mat.eng.osaka-u.ac.jp (T.N.) \\ 2 Faculty of Mechanical Engineering, Istanbul Technical University, 34437 Istanbul, Turkey; \\ bahadira83@gmail.com \\ 3 Department of Chemical Engineering, Northeastern University, Boston, MA 02115, USA; \\ websterthomas02@gmail.com \\ 4 Department of Materials Processing, Tohoku University, Sendai 980-8579, Japan; \\ ueda@material.tohoku.ac.jp (K.U.); narut@material.tohoku.ac.jp (T.N.) \\ * Correspondence: ergunce@itu.edu.tr
}

\section{check for} updates

Citation: Gokcekaya, O.; Ergun, C.; Webster, T.J.; Bahadir, A.; Ueda, K.; Narushima, T.; Nakano, T. Effect of Precursor Deficiency Induced Ca/P Ratio on Antibacterial and Osteoblast Adhesion Properties of Ag-Incorporated Hydroxyapatite: Reducing Ag Toxicity. Materials 2021, 14, 3158. https://doi.org/10.3390/ ma14123158

Academic Editor: Andrew Ruys

Received: 4 May 2021

Accepted: 4 June 2021

Published: 8 June 2021

Publisher's Note: MDPI stays neutral with regard to jurisdictional claims in published maps and institutional affiliations.

Copyright: (c) 2021 by the authors. Licensee MDPI, Basel, Switzerland. This article is an open access article distributed under the terms and conditions of the Creative Commons Attribution (CC BY) license (https:// creativecommons.org/licenses/by/ $4.0 /)$.

\begin{abstract}
Ag-containing hydroxyapatite (HA) can reduce risks associated with bacterial infections which may eventually require additional surgical operations to retrieve a failed implant. The biological properties of HA in such applications are strongly affected by its composition in terms of dopants as well as $\mathrm{Ca} / \mathrm{P}$ stoichiometry, which can be easily controlled by altering processing parameters, such as precursor concentrations. The objective of this in vitro study was to understand the effect of variations in HA precursor solutions on antibacterial properties against Escherichia coli (E. coli) and for promoting osteoblast (bone-forming cell) adhesion on Ag incorporated HA (AgHA) which has not yet been investigated. For this, two groups of AgHAs were synthesized via a precipitation method by adjusting precursor reactants with a stoichiometric value of 1.67 , being either $(\mathrm{Ca}+\mathrm{Ag}) / \mathrm{P}$ (Ca-deficient) or Ca/(P + Ag) (P-deficient), and were characterized by XRD, FTIR, and SEM-EDS. Results showed that $\mathrm{Ag}^{+}$incorporated into the $\mathrm{Ca}^{2+}$ sites was associated with a corresponding $\mathrm{OH}^{-}$ vacancy. Additional incorporation of $\mathrm{CO}_{3}{ }^{2-}$ into $\mathrm{PO}_{4}{ }^{3-}$ sites occurred specifically for the P-deficient AgHAs. While antibacterial properties increased, osteoblast adhesion decreased with increasing Ag content for the Ca-deficient AgHAs, as anticipated. In contrast, significant antibacterial properties with good osteoblast behavior were observed on the P-deficient AgHAs even with a lower Ag content, owing to carbonated HA. Thus, this showed that by synthesizing AgHA using P-deficient precursors with carbonate substitution, one can keep the antibacterial properties of Ag in HA while reducing its toxic effect on osteoblasts.
\end{abstract}

Keywords: hydroxyapatite; silver; carbonate; incorporation; antibacterial; osteoblast adhesion

\section{Introduction}

Hydroxyapatite $\left(\mathrm{HA}, \mathrm{Ca}_{10}\left(\mathrm{PO}_{4}\right)_{6}(\mathrm{OH})_{2}\right)$, one of the main phases of calcium phosphate $(\mathrm{CaP})$, has been investigated as a major mineral component of calcified tissues for several decades [1]. It has been used for various applications in medical applications, such as a drug carrier with controlled release, bone cement, toothpaste additive, or as a coating on metallic implants, for decades [2]. On the other hand, despite its excellent biocompatibility and osteoconductive properties when used as a biomaterial, HA is susceptible to bacterial infections [3]. HA was never designed to reduce bacteria function by itself.

Many biomaterial failures are associated with infection, which grows and can be disruptive to the natural healing process, eventually causing complete implant failure as a result of the development of microbial colonies and biofilms on an implant surface $[4,5]$. 
Infections caused by these organisms are usually treated by traditional systematic drug (antibiotic) administration. These common treatments have numerous drawbacks, such as possible toxicity to mammalian cells as well as low drug penetration into the target tissue [5,6]. Furthermore, there is now a global healthcare crisis in antibiotic-resistant bacteria, which are bacteria that have formed a resistance to antibiotics and can no longer be killed by such antibiotics (such as methicillin-resistant Staphylococcus aureus or MRSA). As an alternative, silver (Ag), as one of the oldest known antibacterial materials, has been used for wound disinfection and also in the treatment of numerous microbial infections $[6,7]$.

However, the antimicrobial action of Ag has not been clearly understood yet, but it is assumed to be facilitated by the release of $\mathrm{Ag}^{+}$to form a strong bond with electron donor groups in biological molecules. Nevertheless, two bacterial mechanisms have been proposed. In the first mechanism, $\mathrm{Ag}^{+}$can first form pits on the bacteria membrane through oxidative reactions and then penetrate the cytoplasm eventually causing cell death [8,9], known as "contact killing". In the second mechanism, $\mathrm{Ag}^{+}$can bind to the microbial DNA in bacteria, preventing bacterial replication, and interacting with sulfhydryl groups on metabolic enzymes of the bacterial electron transport chain $[10,11]$ known as "leach killing". Unfortunately, however, the toxicity of Ag against mammalian cells is still a matter of concern particularly in their utilization as an antimicrobial agent in the human body. It is clear that to take advantage of the antibacterial properties of $\mathrm{Ag}$, how it is incorporated into biomaterials needs to be carefully assessed. As provided by the highly flexible nature of the apatite structure, numerous researchers have tailored apatite properties via ionic substitutions into both cation $\left(\mathrm{Ca}^{2+}\right)$ and anion $\left(\mathrm{PO}_{4}{ }^{3-}\right.$ and $\left.\mathrm{OH}^{-}\right)$sites in its structure [12]. In this respect, Ag incorporated HA (AgHA) has been widely studied to provide antimicrobial activity while maintaining the bioactivity of implants, providing bacterial inhibition, and enhancing osteoblast functions [13-15].

Thus, Ag can indeed be used as an implant material to prevent biomaterial-related post-implantation infections, a substantial problem affecting the long-term in vivo performance of implants, possibly leading to surgery to remove the failed implant in order to save a patient's life [16,17]. However, the cytotoxicity of released $\mathrm{Ag}^{+}$from $\mathrm{AgHA}$ still needs to be addressed as one of the main questions to determine the optimal Ag concentration to ensure both effectiveness against bacteria at the implant surface and safeness against the cytotoxic effect on nearby cells [18]. The vast majority of the studies focused on optimizing the amount of $\mathrm{Ag}$ to obtain antibacterial properties while maintaining mammalian cell activities [6-15]. However, this study focused on altering the HA structure with a precursor deficiency approach for the first time ever in the literature (to the best of the authors' knowledge).

Chemical precipitation is a simple and cost-effective process for synthesizing AgHA particles [19]. Based on this process, the physicochemical properties of the synthesized particles are mainly controlled by several process parameters, i.e., temperature, $\mathrm{pH}$, and the concentration of the precursors in an aqueous medium. During the synthesis of AgHA, the starting reactants are added into precursor solutions in appropriate molar proportions based on the desired final stoichiometry. In some research, assuming $\mathrm{Ag}^{+}$incorporation into Ca positions, a certain amount of Ca precursor chemicals were replaced with $\mathrm{Ag}$ precursor chemicals on a molar basis to counterbalance the resulting Ca-deficient precursor and maintain the cation $(\mathrm{Ca}+\mathrm{Ag}) / \mathrm{P}$ atomic ratio at 1.67 [20]. In some other HA materials, $P$ precursor chemicals were replaced with a dopant precursor chemical to counterbalance the resulting $\mathrm{P}$-deficient precursor and maintain the cation $\mathrm{Ca} /(\mathrm{P}+$ dopant $)$ atomic ratio at 1.67 [21], however, this assumption has not been applied in terms of $\mathrm{Ag}^{+}$incorporation. Even yet, in some other research, the reactants as dopant sources were directly added to precursor solutions even without any compensation to maintain the respected atomic ratio at 1.67, which can be defined as an extra precursor [22-25].

In fact, the solid solubility of Ag ions in the HA structure, in terms of the $\mathrm{Ag} /(\mathrm{Ca}+$ $\mathrm{Ag}$ ) atomic ratio, has been reported to be in the range of 0.0019-0.0061 [20]. In this solid solution, Ag incorporation into the Ca-site is suggested to be highly probable and the 
amount of $\mathrm{Ag}$ can be as much as an $\mathrm{Ag} /(\mathrm{Ca}+\mathrm{Ag})$ atomic ratio of 0.0909 [26,27]. On the other hand, a small amount of Ag incorporation into the P-site is suggested to be possible with a $\mathrm{Ag}$ amount corresponding to an $\mathrm{Ag} /(\mathrm{Ca}+\mathrm{Ag})$ atomic ratio of 0.016 [26].

Obviously, the difference in the precursor preparation to replace some $\mathrm{Ca}$ ions or $\mathrm{P}$ ions with $\mathrm{Ag}$ ions is based on the assumption that $\mathrm{Ag}$ will incorporate into $\mathrm{Ca}$ or $\mathrm{P}$ sites, and will energetically favor a particular resultant phase/s, eventually, determining the final properties of the incorporated HA. As a result, there is a bias to choose one of these approaches regarding Ca-deficiency or P-deficiency to optimize biological or other physicochemical properties for AgHA.

In this sense, the biological response of AgHAs should be evaluated depending on the Ag content as the characteristic of the precursor chemistry [26], to precisely tailor its final properties and to make correct predictions about its performance in real medical applications. With this motivation in mind, to the best of the authors' knowledge, this in vitro study was conducted for the first time to systematically elucidate the effect of the stoichiometric value of 1.67 obtained via either $(\mathrm{Ca}+\mathrm{Ag}) / \mathrm{P}(\mathrm{Ca}$-deficient $)$ or $\mathrm{Ca} /(\mathrm{P}+\mathrm{Ag})$ (P-deficient) atomic ratios in precursor solutions (possessing 0.2 and $0.5 \mathrm{~mol} \mathrm{Ag}$ addition) on antibacterial properties and osteoblast (bone-forming cell) adhesion. In doing so, this study provides a new way to synthesize AgHA to retain the antibacterial properties of $\mathrm{Ag}$ with reduced toxicity to osteoblasts.

\section{Materials and Methods}

\subsection{Synthesis and Characterization}

Pure HA and AgHAs were synthesized according to a well-established precipitation method [28]. Briefly, for pure HA synthesis, calcium nitrate $\left(\mathrm{Ca}\left(\mathrm{NO}_{3}\right)_{2} \cdot 4 \mathrm{H}_{2} \mathrm{O}\right.$ (Alfa Aesar, Karlsruhe, Germany; $99.99 \%$ purity)) and ammonium phosphate $\left(\mathrm{NH}_{4}\right)_{3} \mathrm{PO}_{4}$ (Alfa Aesar, Karlsruhe, Germany; $99.99 \%$ purity)) solutions were separately brought to a $\mathrm{pH}$ of $11-12$ with aqueous ammonia $\left(\mathrm{NH}_{4} \mathrm{OH}, 25 \%\right.$ (Alfa Aesar, Karlsruhe, Germany; $99.99 \%$ purity)). The $1 \mathrm{M} \mathrm{Ca}\left(\mathrm{NO}_{3}\right)_{2} \cdot 4 \mathrm{H}_{2} \mathrm{O}$ solution was stirred vigorously at room temperature (RT), and the $0.6 \mathrm{M}\left(\mathrm{NH}_{4}\right)_{3} \mathrm{PO}_{4}$ solution was added dropwise into this $\mathrm{Ca}\left(\mathrm{NO}_{3}\right)_{2} \cdot 4 \mathrm{H}_{2} \mathrm{O}$ solution to produce a gelatinous precipitate. The precipitated solution was stirred for $24 \mathrm{~h}$ at $\mathrm{RT}$ to form pure HA powders.

In order to synthesize $\mathrm{AgHA}$ [29], reagent grade silver nitrate $\left(\mathrm{AgNO}_{3}\right.$ (Alfa Aesar, Karlsruhe, Germany; $99.99 \%$ purity)) was added into the $\mathrm{Ca}\left(\mathrm{NO}_{3}\right)_{2} \cdot 4 \mathrm{H}_{2} \mathrm{O}$ solution. Ag incorporation into $\mathrm{Ca}$ or $\mathrm{P}$ ions was chosen at either $0.2 \mathrm{~mol}$ or $0.5 \mathrm{~mol}$. There was a goal to achieve a stoichiometric value of 1.67 for the $(\mathrm{Ca}+\mathrm{Ag}) / \mathrm{P}$ or $\mathrm{Ca} /(\mathrm{P}+\mathrm{Ag})$ atomic ratios, therefore, the atomic ratios of $\mathrm{Ca}$ or $\mathrm{P}$ ions were deliberately added at $0.2 \mathrm{~mol}$ or $0.5 \mathrm{~mol}$ less than that required for pure HA into the Ca deficient (C2 and C5) or P deficient (P2 and P5) precursor solutions, respectively, to compensate for the difference with Ag ions.

Additionally, samples were prepared for comparison purposes with the addition of $0.2 \mathrm{~mol} \mathrm{Ag}$ (E2) to stoichiometric HA precursor solutions without any compensation in either Ca or P precursors. The description and the composition of the samples are shown in Table 1.

The reaction mixture was centrifuged and washed repeatedly with deionized water to remove the unreacted ionic species and ammonia solution. Next, the as-precipitated powders were filtered using a $0.2-\mu \mathrm{m}$ filter paper, and then dried for at least $48 \mathrm{~h}$ at $60^{\circ} \mathrm{C}$. Dried powders were crushed and passed through a 200-mesh screen to obtain a powder with particle sizes $<75 \mu \mathrm{m}$ in diameter. 
Table 1. The charged composition and atomic ratios of the Ag-HA series of interest to the present study.

\begin{tabular}{ccccccccc}
\hline & & \multicolumn{3}{c}{ Charged Molar Ratios } & \multicolumn{3}{c}{ Charged Atomic Ratios } \\
\cline { 2 - 8 } & & $\mathbf{C a}$ & $\mathbf{P}$ & $\mathbf{A g}$ & $\mathbf{C a} / \mathbf{P}$ & $\mathbf{( C a}+\mathbf{A g}) / \mathbf{P}$ & $\mathbf{C a} /(\mathbf{P}+\mathbf{A g})$ & $\mathbf{A g} /(\mathbf{C a}+\mathbf{A g})$ \\
\hline Pure HA & HA & 10 & 6 & 0 & 1.67 & - & - & - \\
\hline Extra Ag containing HA & E2 & 10 & 6 & 0.2 & 1.67 & - & - & - \\
\hline Ag ions exchanged with & C2 & 9.8 & 6 & 0.2 & - & 1.67 & - & 0.0196 \\
Ca-precursor & C5 & 9.5 & 6 & 0.5 & - & - & 1.67 & 0.050 \\
\hline Ag ions exchanged with & P2 & 10 & 5.8 & 0.2 & - & - & 0.0196 \\
P-precursor & P5 & 10 & 5.5 & 0.5 & - & 0.0476 \\
\hline
\end{tabular}

$0.5 \mathrm{~g}$ of pure HA and AgHA powders were cold-pressed into $10 \mathrm{~mm}$ diameter cylindrical pellets under $100 \mathrm{MPa}$ pressure. Subsequently, the pellets were heat-treated at $700{ }^{\circ} \mathrm{C}$, $900{ }^{\circ} \mathrm{C}, 1100^{\circ} \mathrm{C}$, and $1300^{\circ} \mathrm{C}$ (ramp rate of $22^{\circ} \mathrm{C} / \mathrm{min}$ ) for $2 \mathrm{~h}$. The phases of the heat-treated samples were confirmed by X-ray diffraction (XRD, Philips PW2273/20, Kyoto, Japan).

The chemical composition of AgHAs was measured by scanning electron microscopy (SEM, JEOL JSM-840, Tokyo, Japan) equipped with energy-dispersive X-ray spectroscopy (EDS). The measured composition values were standardized with commercial calcium pyrophosphate $(\mathrm{CPP}, \mathrm{Ca} / \mathrm{P}=1.0)$, tricalcium phosphate $(\mathrm{TCP}, \mathrm{Ca} / \mathrm{P}=1.5), \mathrm{HA}(\mathrm{Ca} / \mathrm{P}=1.67)$, and tetra calcium phosphate (TTCP, $\mathrm{Ca} / \mathrm{P}=2.0$ ). Fourier transform infrared (FTIR, JASCO, FT/IR-460Plus, Tokyo, Japan) spectroscopy was used to identify the functional groups and the presence of bonds formed in the heat-treated AgHAs. The model HA crystal structure was visualized with VESTA [30], according to the FTIR observations, and was proposed for AgHAs regarding Ca-deficiency or P-deficiency.

Grain size of the heat-treated pure HA and AgHAs was investigated by SEM. The densities of the cylindrical samples were calculated from their measured dimensions and mass. A parameter defined as the densification factor $(D F)$ was used to monitor the density changes of AgHAs during the heat-treatment at different temperatures. This factor was calculated with respect to ref. [31] with the following equation:

$$
D F=\frac{D-D_{g}}{D_{g}} \times 100
$$

where $D$ is the density of the heat-treated samples and $D_{g}$ is the density of the cold-press powders.

\subsection{In Vitro Evaluation}

Only the pure $\mathrm{HA}$ and AgHAs heat-treated at $1100{ }^{\circ} \mathrm{C}$ were subjected to in vitro experiments to evaluate the effect of Ag incorporation into the HA structure on the respective biological behavior. Specifically, the bactericidal activity of AgHAs in the nutrient broth solution $\left(\mathrm{NB},\left[\mathrm{Cl}^{-}\right]=100 \mathrm{mM}\right)$ was evaluated with the turbidimetric method. The details of this method were described elsewhere [15]. Briefly, the samples were placed in polypropylene (PP) test tubes and autoclaved at $121^{\circ} \mathrm{C}$ under steam pressure for $21 \mathrm{~min}$. Subsequently, they were exposed to $5 \mathrm{~mL}$ of an Escherichia coli (E. coli, DH5 $\alpha$ ) containing NB solution for $6 \mathrm{~h}$ while being shaken at $200 \mathrm{rpm}$ and incubated at $37^{\circ} \mathrm{C}$, in which the control group reached $8 \times 10^{8}$ colony-forming units $(\mathrm{CFU}) \cdot \mathrm{mL}^{-1}$. The tests were conducted with five heat-treated pellets with triplicate measurements from each sample.

Bacterial cultures without any powder were also incubated and used as a control group. After incubation, optical densities $(O D)$ of the control and AgHA containing NB solutions were measured at $600 \mathrm{~nm}$ using a UV-vis spectrophotometer (Shimadzu BioSpec-1600, Kyoto, Japan). 
A parameter defined as the bactericidal ratio was used to compare and evaluate the bactericidal properties of the samples. This ratio was calculated with the following equation [15]:

$$
\text { Bactericidal ratio }(\%)=\frac{\text { OD of control group }- \text { OD of experimental group }}{\text { OD of control group }} \times 100
$$

Human osteoblasts (bone-forming cells; CRL-11372; ATCC) were cultured in Dulbecco's modified Eagle's medium (DMEM; GIBCO) supplemented with $10 \%$ fetal bovine serum (FBS; Hyclone) and 1\% penicillin/streptomycin (P/S; Hyclone) under standard cell culture conditions $\left(37^{\circ} \mathrm{C}\right.$, humidified, $5 \% \mathrm{CO}_{2} / 95 \%$ air environment). All heat-treated pellets were sterilized and placed in 12-well tissue culture plates and were rinsed three times with sterilized phosphate-buffered saline (PBS). Osteoblasts were seeded at a concentration of 2500 cells $\cdot \mathrm{cm}^{-2}$ onto the samples of interest in DMEM supplemented with $10 \%$ FBS and $1 \% \mathrm{P} / \mathrm{S}$ and were then incubated under standard cell culture conditions for $4 \mathrm{~h}$ [32]. After incubation, non-adherent cells were removed by rinsing with PBS, and adherent cells were then fixed with formaldehyde (Fisher Scientific, Hampton, NH, USA) and stained with Hoechst 33258 dye (Sigma Aldrich, St. Louis, MD, USA); the cell nuclei were, thus, visualized and counted under a fluorescence microscope. Cell counts were expressed as the average number of cells on eight random places per sample.

Borosilicate glass coverslips (reference material) were etched in $1 \mathrm{~N}$ of $\mathrm{NaOH}$ according to a standard protocol and used as a reference material in the experiments [32]. Additionally, pure HA was used as another reference material in the experiment to highlight the effect of the incorporated Ag ions. Osteoblast counts were expressed as the average number of cells on eight random places per sample.

\subsection{Statistical Analysis}

All in vitro experiments were carried out with five pellets, each sample in triplicate, and cell adhesion was evaluated based on the mean number of adherent cells while the bactericidal ratio was determined with $O D$ values. Numerical data from the in vitro antibacterial and osteoblast adhesion experiments were analyzed using standard analysis of variance (ANOVA) techniques and statistical significance was considered at $p<0.05$.

\section{Results}

\subsection{Material Characterization}

According to the spectral analysis (Table 2), pure HA had a $\mathrm{Ca} / \mathrm{P}$ atomic ratio of 1.69 which is quite comparable to the ideal stoichiometric value of 1.67. However, E2 exhibited the highest $\mathrm{Ca} / \mathrm{P}$ atomic ratio (2.06), indicating a possible $\mathrm{P}$ depletion from the HA structure. C2, C5, P2, and P5 had standardized Ca/P atomic ratios of 1.99, 1.81, 1.91, and 1.99, respectively. Moreover, $\mathrm{C} 2$ and $\mathrm{C} 5$ possessed $\mathrm{Ag} /(\mathrm{Ca}+\mathrm{Ag})$ atomic ratios of 0.0025 and 0.0061 respectively. Furthermore, P2 and P5 possessed $\mathrm{Ag} /(\mathrm{Ca}+\mathrm{Ag})$ atomic ratios of 0.0017 and 0.0050 , respectively, which correlated well with the previous report [19]. These results revealed that the $\mathrm{Ca} / \mathrm{P}$ atomic ratio decreased with increased $\mathrm{Ag}$ content in the Ca-deficient AgHAs, and, in contrast, an increase in P-deficient AgHAs.

On the other hand, E2 had a relatively lower Ag content compared to its counterparts which presumably seemed to be due to the inability of Ag ions in the precursor solutions to incorporate into the HA structure during the precipitation. The $\mathrm{Ag}$ cations might have reacted with $\mathrm{P}$ ions in the precursor solution possibly forming $\mathrm{Ag}_{3} \mathrm{PO}_{4}$ precipitates as reported in [20] during the synthesis. Therefore, E2 may have a higher $\mathrm{Ca} / \mathrm{P}$ atomic ratio (Table 2). 
Table 2. Measured composition and atomic ratios of the AgHA series heat treated at $1100{ }^{\circ} \mathrm{C}$ and corresponding average grain sizes.

\begin{tabular}{|c|c|c|c|c|c|}
\hline & \multirow{2}{*}{$\begin{array}{l}\text { Intended } \\
\mathrm{Ca} / \mathbf{P}\end{array}$} & \multicolumn{2}{|c|}{ Measured Atomic Ratios } & \multirow{2}{*}{$\begin{array}{c}\text { Concentration Factor }(\mathrm{CF}) \\
\mathrm{Ag} /(\mathrm{Ag}+\mathrm{Ca}+\mathrm{P})\end{array}$} & \multirow{2}{*}{$\begin{array}{c}\text { Average Grain Size } \\
(\mu \mathrm{m})\end{array}$} \\
\hline & & $\mathrm{Ca} / \mathrm{P}$ & $\mathrm{Ag} /(\mathrm{Ca}+\mathrm{Ag})$ & & \\
\hline HA & 1.67 & 1.69 & - & - & 5.8 \\
\hline E2 & 1.67 & 2.06 & 0.0004 & 0.0003 & 8.6 \\
\hline $\mathrm{C} 2$ & 1.63 & 1.99 & 0.0025 & 0.0017 & 5.3 \\
\hline C5 & 1.58 & 1.81 & 0.0061 & 0.0042 & 3.3 \\
\hline $\mathrm{P} 2$ & 1.72 & 1.91 & 0.0017 & 0.0011 & 10.6 \\
\hline P5 & 1.82 & 1.99 & 0.0050 & 0.0035 & 6.6 \\
\hline
\end{tabular}

XRD patterns of the pure HA and AgHAs heat-treated at $700{ }^{\circ} \mathrm{C}, 900{ }^{\circ} \mathrm{C}, 1100{ }^{\circ} \mathrm{C}$, and $1300{ }^{\circ} \mathrm{C}$ are presented in Figures 1 and 2, respectively. All patterns (being closely matched to JCPDS\#9-0432) revealed that HA was the main phase in all samples. However, as indicated by the relatively broader peaks, it was partially crystallized at $700{ }^{\circ} \mathrm{C}$ and almost fully crystallized at $900{ }^{\circ} \mathrm{C}$ for all samples. The crystallinity of the HA phase seems to be more dominant in the pure HA than in the AgHAs at all temperatures, which may be due to the smaller particle size and/or partial disorderliness, most probably resulting from $\mathrm{Ag}$ incorporation into the HA structure as well as the corresponding formation of the other structural defects.
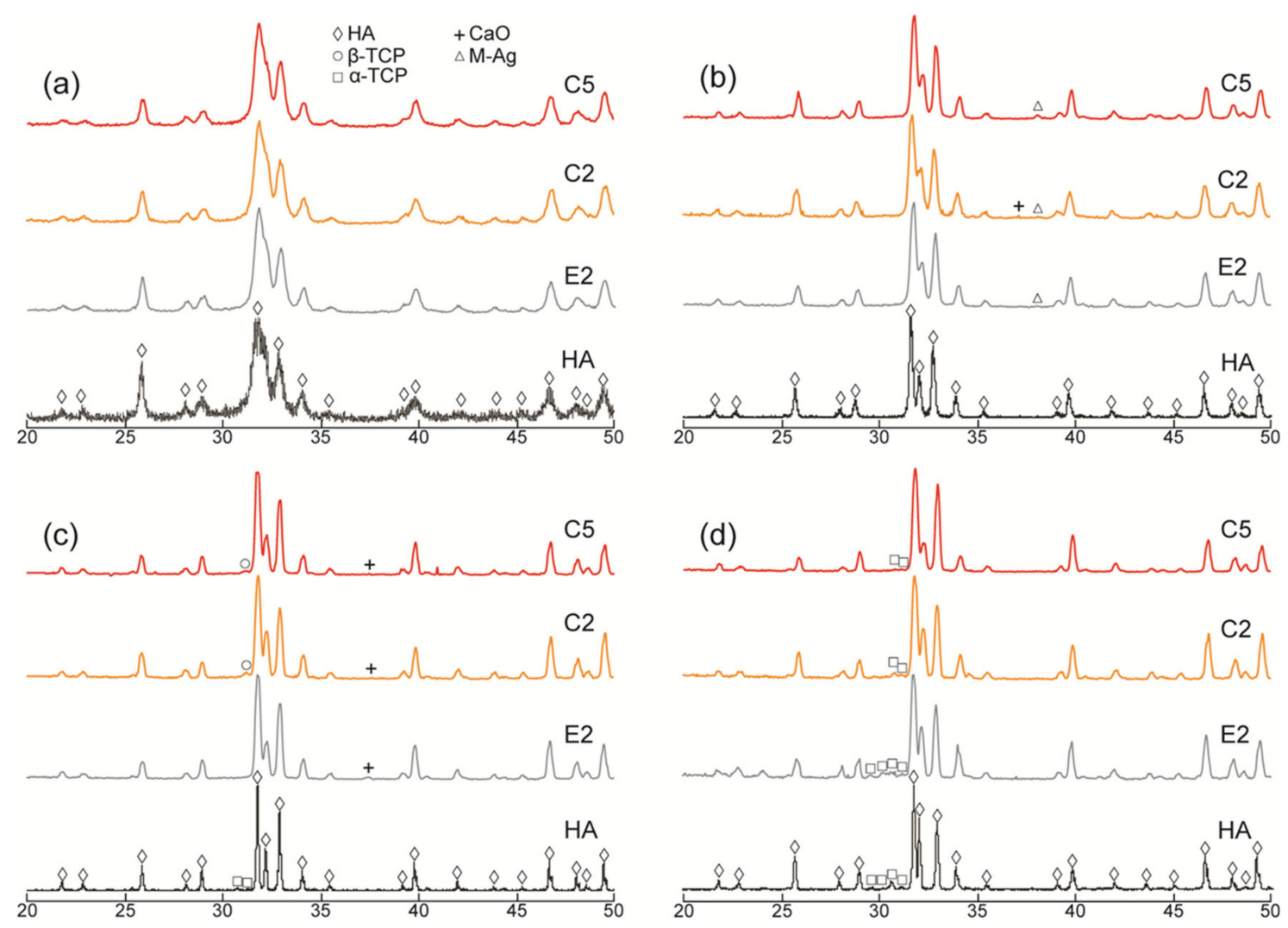

Figure 1. XRD patterns of the Ca-deficient (C2 and C5) AgHAs compared to E2 and pure HA heat-treated at (a) $700{ }^{\circ} \mathrm{C}$, (b) $900{ }^{\circ} \mathrm{C}$, (c) $1100{ }^{\circ} \mathrm{C}$, and (d) $1300{ }^{\circ} \mathrm{C}$. Y-axis: arbitrary unit. 

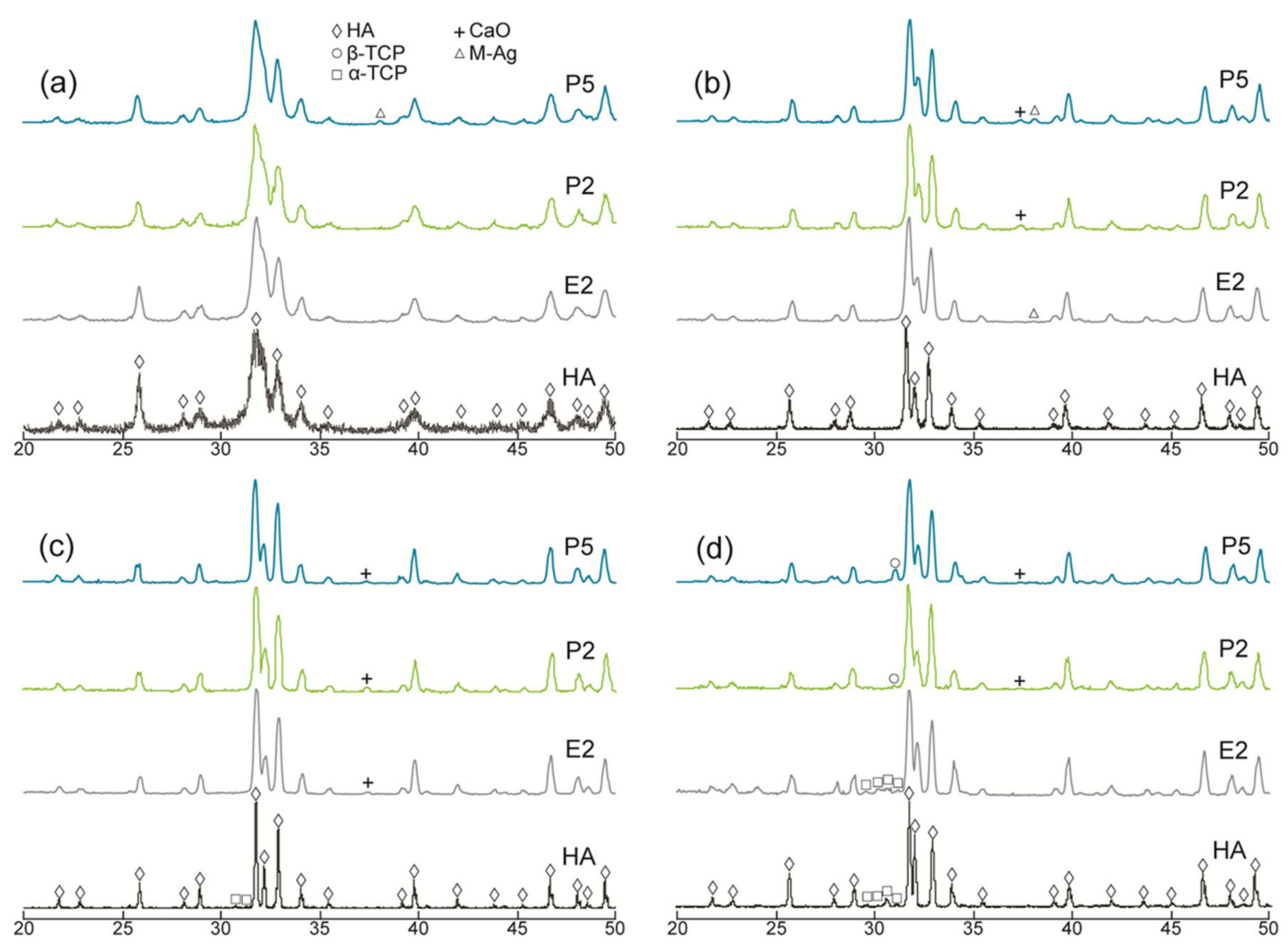

Figure 2. XRD patterns of the P-deficient AgHAs compared to E2 and pure HA heat-treated at (a) $700{ }^{\circ} \mathrm{C}$, (b) $900{ }^{\circ} \mathrm{C}$, (c) $1100^{\circ} \mathrm{C}$, and (d) $1300^{\circ} \mathrm{C}$. Y-axis: arbitrary unit.

In the meantime, a slight amount of metallic $\mathrm{Ag}$, as a minor phase, was detected in all AgHAs at $900{ }^{\circ} \mathrm{C}$ (Figures 1 and 2), except P2 perhaps due to its relatively lower Ag content (Table 2). Furthermore, the metallic Ag seemed to disappear at $1100{ }^{\circ} \mathrm{C}$, most probably due to incorporation into the HA and/or $\beta$-TCP phases with possible solid-state diffusion [26].

$\alpha$-TCP was observed only in pure HA at $1100{ }^{\circ} \mathrm{C}$ as a result of the partial decomposition of the HA phase. However, a slight amount of $\beta$-TCP was observed in Ca-deficient AgHAs at $1100{ }^{\circ} \mathrm{C}$, while it transformed into $\alpha$-TCP at $1300{ }^{\circ} \mathrm{C}$ (Figure $1 \mathrm{c}$ ). On the contrary, P-deficient AgHAs showed no apparent decomposition of HA at $1100{ }^{\circ} \mathrm{C}$ (Figure 2c), whereas, they showed a partial decomposition of HA, forming only a slight amount of $\beta$-TCP at $1300{ }^{\circ} \mathrm{C}$ (Figure $2 \mathrm{~d}$ ).

The FTIR spectra of HA and AgHAs illustrated in Figure 3 showed systematic changes in phosphate, hydroxyl, and carbonate bands as a response to the changing sample type and increasing Ag content. For instance, the strong peaks in the range $900-1200 \mathrm{~cm}^{-1}$ attributed to $\mathrm{P}-\mathrm{O}$ stretching vibration modes of phosphate groups showed a decrease in intensity with an increase in Ag content. On the other hand, the peak observed at $1630 \mathrm{~cm}^{-1}$ assigned to the vibration band of the lattice of water did not show any significant change. 


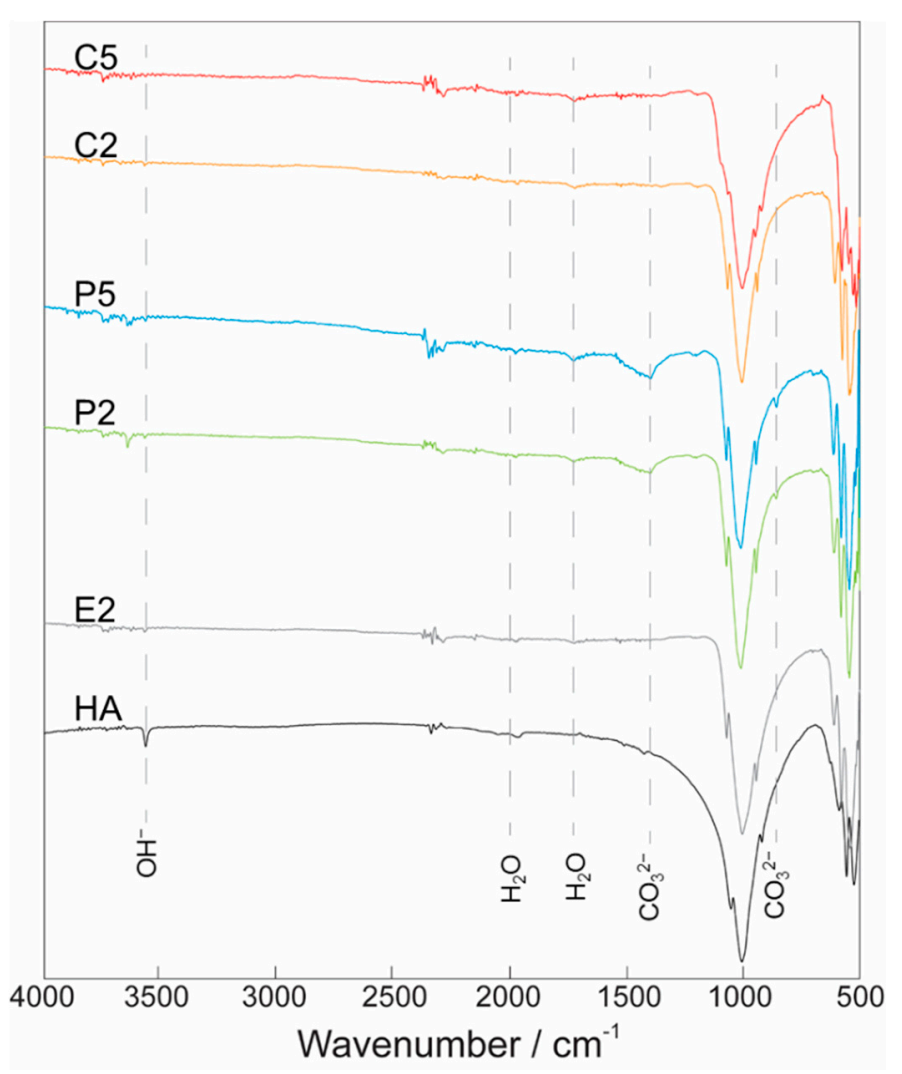

Figure 3. FTIR spectra for Ca-deficient (C2 and C5) and P-deficient (P2 and P5) AgHAs compared to $\mathrm{E} 2$ and pure HA heat-treated at $1100{ }^{\circ} \mathrm{C}$. Y-axis: arbitrary unit.

The peaks observed in the range of $1400-1500 \mathrm{~cm}^{-1}$ and $885 \mathrm{~cm}^{-1}$ in the P2 and P5 samples can be attributed to the asymmetric stretching vibration of $\mathrm{CO}_{3}{ }^{2-}$, particularly corresponding to B-type carbonate groups that specifically incorporated into the phosphate sites [33]. In contrast, no peak was identified as evidence for the existence of A-type carbonate [34]. In the meantime, the peak of the band at $3570 \mathrm{~cm}^{-1}$ attributed to the stretching vibration of $\mathrm{OH}^{-}$in the $\mathrm{HA}$ structure almost completely disappeared from the FTIR spectra of E2, P2, P5, C2, and C5 (Figure 3).

The results from the SEM studies (Figure 4) showed that HA, C2, and C5 possessed a small amount of porosity at $1100{ }^{\circ} \mathrm{C}$, providing evidence for the possible thermal decomposition of the HA main phase, as indicated by the XRD results. The average grain size of these samples was $5.8 \mu \mathrm{m}, 5.3 \mu \mathrm{m}$, and $3.3 \mu \mathrm{m}$, respectively (Table 2). However, the average grain sizes of E2, P2, and P5, showing no phase decomposition, were $8.6 \mu \mathrm{m}$, $10.6 \mu \mathrm{m}$, and $6.6 \mu \mathrm{m}$, respectively. 

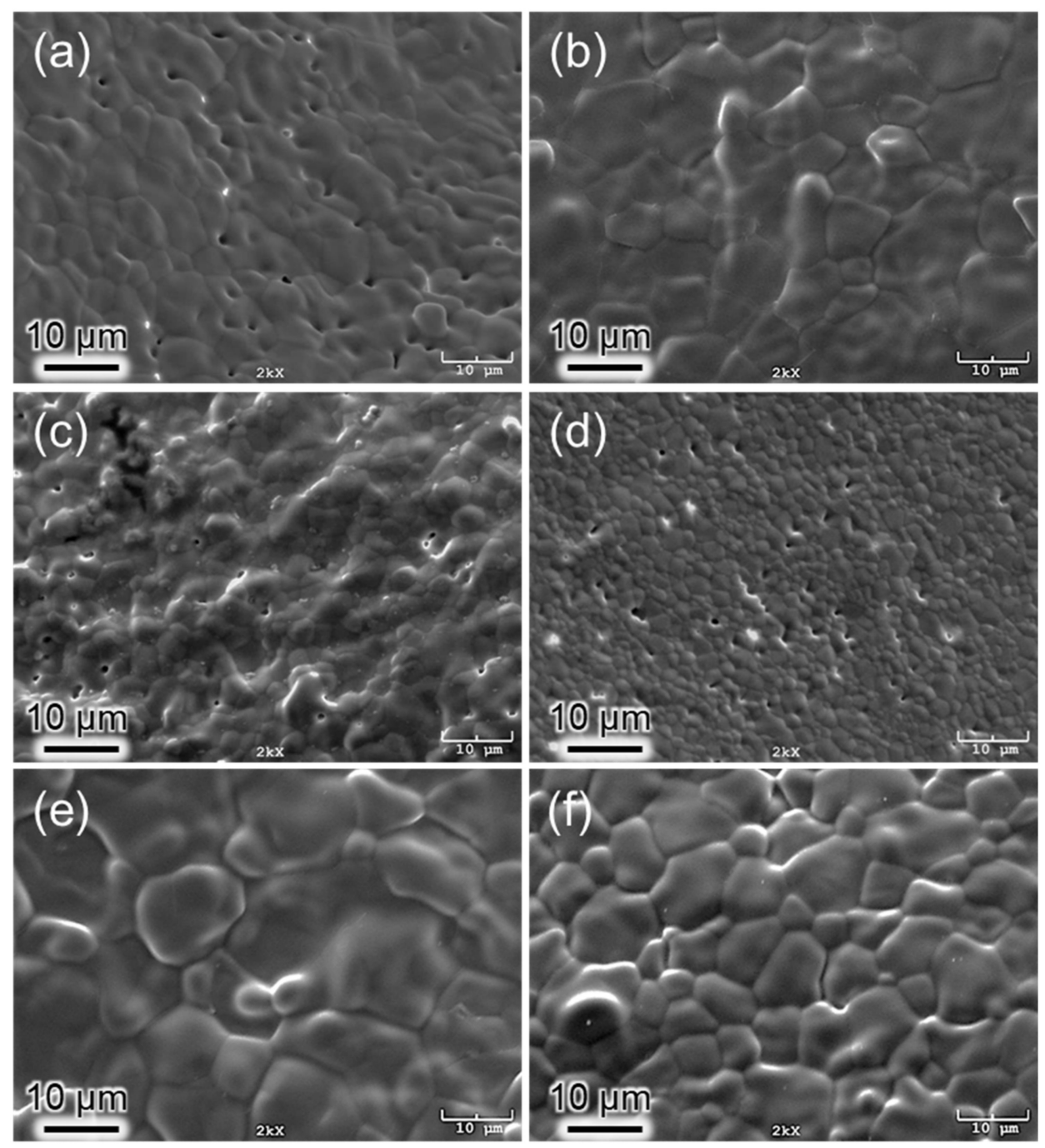

Figure 4. SEM images of AgHAs and pure HA heat-treated at $1100{ }^{\circ} \mathrm{C}$ : (a) HA, (b) E2, (c) C2, (d) C5, (e) P2, and (f) P5. (Scale bar $=10 \mu \mathrm{m})$.

\subsection{Densification}

The densification factor (DF) of the samples calculated using Equation (1) is given in Figure 5. The DF values of the samples showed a steep increase with an increase in the heattreatment temperature from $700{ }^{\circ} \mathrm{C}$ to $1100{ }^{\circ} \mathrm{C}$. Apparently, the increase in densification occurred earlier, particularly in $\mathrm{P} 2$, and the $\mathrm{P} 5$ samples at a lower temperature range and later for $\mathrm{E} 2, \mathrm{C} 2$, and $\mathrm{C} 5$ at a higher temperature range. The $\mathrm{DF}$ of $\mathrm{C} 2$ was the highest among the samples at $1100{ }^{\circ} \mathrm{C}$ and $1300{ }^{\circ} \mathrm{C}$. In contrast, the $D F$ of $\mathrm{C} 5$ was always the smallest at all temperatures, which can be related to the dehydration of the $\mathrm{OH}^{-}$group [31] and a subsequent phase decomposition during the heat treatment detected with XRD analysis, which releases $\mathrm{H}_{2} \mathrm{O}$ as a reaction product as discussed by Ou et al. [35] and resulted in differences in the thermal expansion of HA and $\beta$-TCP [36]. This result can be related to the porosities observed in the SEM micrograph (Figure 4). 


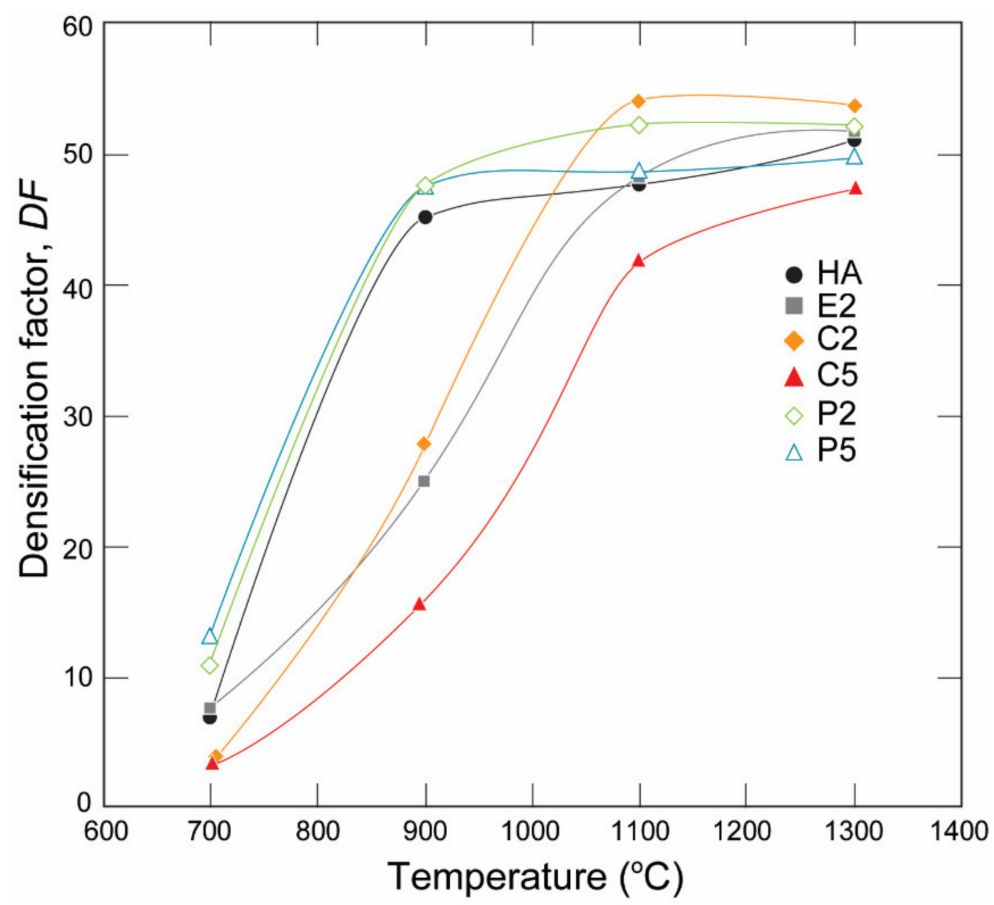

Figure 5. Densification factor of the HA, C-Ag and P-AgHA series.

\subsection{Bactericidal Effect}

The bactericidal ratios of the samples of interest in this study as calculated with Equation (2) are given in Figure 6. The descending order in bactericidal ratios from this study was $\mathrm{C} 5>\mathrm{P} 2>\mathrm{C} 2>\mathrm{P} 5>\mathrm{HA}$, while the control group reached $8 \times 10^{8} \mathrm{CFU} \mathrm{mL}^{-1}$ bacteria concentration after $6 \mathrm{~h}$ of incubation, which is quite a high bacteria concentration considering that clinical infection occurs at about a $1 \times 10^{5} \mathrm{CFU} \mathrm{mL} \mathrm{mb}^{-1}$ bacteria concentration.

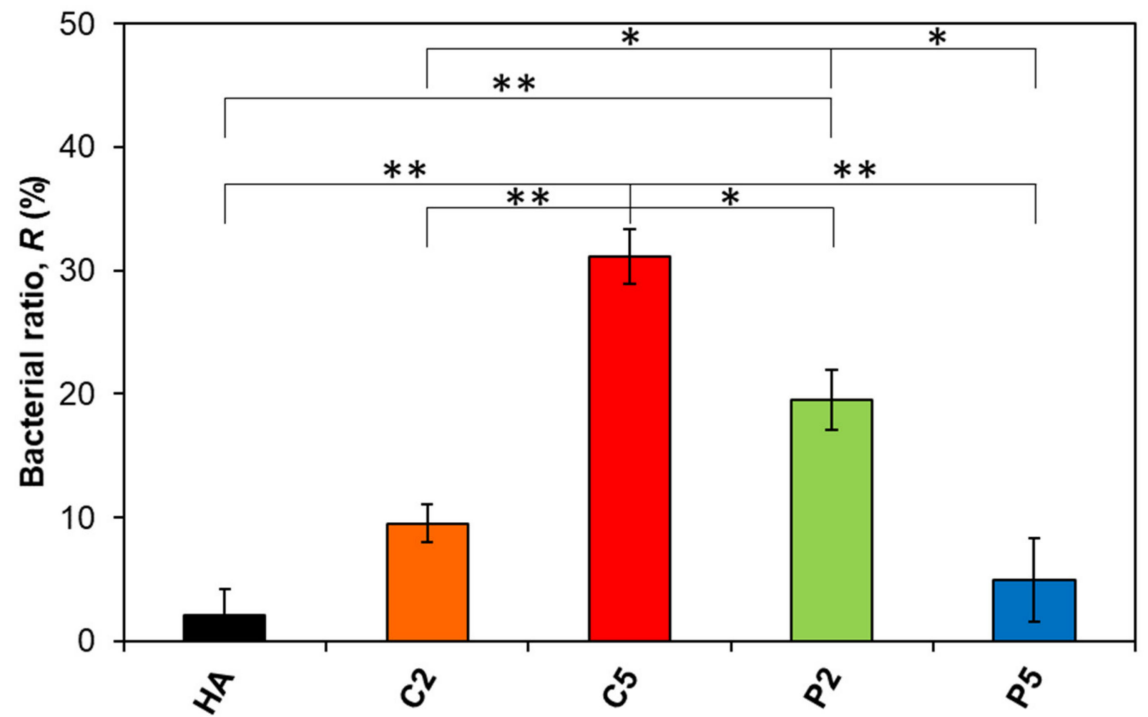

Figure 6. Change in the bactericidal ratio of the AgHA series. $\left({ }^{* *} p<0.01,{ }^{*} p<0.05\right)$.

The ratio was $2.1 \%$ for pure HA, which was the minimum value among the samples. On the other hand, the ratio increased to $9.5 \%$ for $\mathrm{C} 2$ and further increased to $31.1 \%$ for C5. These results seem to be quite plausible since C5 had a higher Ag content than C2 (Table 2). In contrast, the ratio was approximately $20 \%$ for P2 which is higher than that for $\mathrm{C} 2$ despite its relatively lower Ag content. Interestingly, the ratio further decreased 
to $4.9 \%$ for P5 despite an even higher Ag content than both P2 and C2 (Table 2). As a result, increasing the Ag content increased the bactericidal ratio in the Ca-deficient AgHAs, which in contrast, decreased in the P-deficient ones. Moreover, P2 exhibited a significant difference in bactericidal ratio compared to HA, even C2 and P5 with higher Ag content.

\subsection{Osteoblast Adhesion}

Results of osteoblast adhesion to the samples after $4 \mathrm{~h}$ are shown in Figure 7 . The difference in osteoblast adhesion on the AgHA was statistically insignificant except for P5 compared to that on pure HA. The mean value of viable osteoblasts was the highest for C2, being better than pure HA with a factor of 1.5. In contrast, osteoblast adhesion exhibited a considerable decrease for C5, which is not surprising since it had a higher Ag content than C2. On the other hand, the mean value of viable osteoblasts on the P2 sample was interestingly lower than on C2 despite its lower Ag content. More interestingly, the number of viable cells decreased on the P5 samples, being a much lower value than that on C5 with a factor of about 15.6, in spite of its slightly lower Ag content.

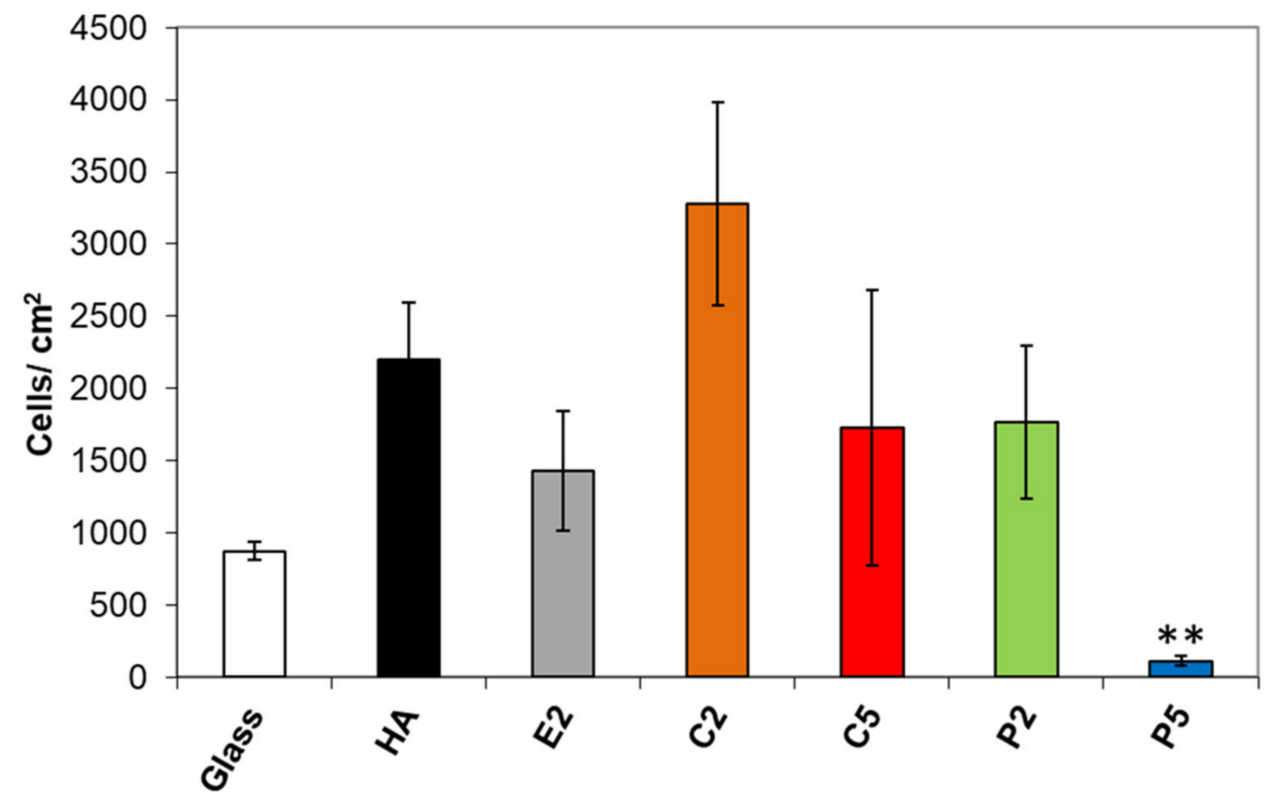

Figure 7. Change in osteoblast adhesion on the AgHA series. ( ${ }^{* *} p<0.01$; compared to HA).

\section{Discussion}

\subsection{The Effect of a Deficient Precursor Approach on the AgHA Structure}

The AgHAs synthesized from the Ca-deficient precursors, namely C2 and C5, showed a partial decomposition in the HA phase forming a slight amount of $\beta$-TCP upon heat treatment at $1100{ }^{\circ} \mathrm{C}$ [13]. In contrast, the AgHAs synthesized from the P-deficient precursors, namely P2 and P5, stayed mainly stable at $1100^{\circ} \mathrm{C}$, while a slight amount of $\beta$-TCP became apparent at $1300^{\circ} \mathrm{C}$. For comparison, HA and E2 were considered, which presented a similar structural decomposition to $\alpha$-TCP at $1300{ }^{\circ} \mathrm{C}$ which is higher than the $\beta \rightarrow \alpha$ transformation temperature (around $1140^{\circ} \mathrm{C}$ ). In this regard, the Ag ion can be considered as a $\beta$-TCP stabilizing agent upon incorporation into the HA structure [20], especially for the P-deficient precursors in this study.

In order to compare the Ag content in AgHAs for the heat-treated conditions, a parameter called the concentration factor $\left(\mathrm{CF}=\frac{\mathrm{Ag}}{\mathrm{Ag}+\mathrm{Ca}+\mathrm{P}}\right)$, was calculated based on the results of the elemental analysis (Table 2). The CFs for C2 and C5 were 0.0017 and 0.0042 , respectively. On the other hand, the respective values for P2 and P5 were 0.0011 and 0.0035, respectively. Therefore, it seems that a higher amount of Ag incorporation became possible when synthesized from the Ca-deficient precursors. Upon considering the 
estimated solubility limit of $\mathrm{Ag}$ (described as the $\mathrm{Ag} /(\mathrm{Ca}+\mathrm{Ag})$ atomic ratio) being in the range of 0.0019-0.0061 [20], the Ag content in C5 reached the highest in this study at 0.0061, which seemed to be in a good agreement with the literature [20,26,37]. However, E2 showed a considerably lower Ag content (0.0004 atomic ratio), highlighting the effectiveness of using deficient precursor approaches in successful $\mathrm{Ag}$ incorporation in the HA structure. Therefore, the lack of $\mathrm{Ag}$ incorporation in $\mathrm{E} 2$ and a high $\mathrm{Ca} / \mathrm{P}$ atomic ratio was predicted to be the result of possible $\mathrm{Ag}_{3} \mathrm{PO}_{4}$ formation during the precipitation process as mentioned in Section 3.1. Thus, further discussion here is mainly focused on the synthesis by Ca-deficient and P-deficient precursors.

FTIR results showed that the P-O stretching bands $\left(900-1200 \mathrm{~cm}^{-1}\right)$ became weaker upon Ag incorporation as observed in all AgHAs compared to the pure HA. Indeed, as reported in the literature, the incorporation of larger cations, such as $\mathrm{Sr}^{2+}$, into Ca sites is expected to cause weakening in the $\mathrm{P}-\mathrm{O}$ stretching bands because of the formation of a subsequent larger anion-anion separation, while the incorporation of smaller cations, such as $\mathrm{Mg}^{2+}$, is expected to show strengthening in the $\mathrm{P}-\mathrm{O}$ stretching bands because of the smaller anion-anion separation that it causes [38]. In this regard, it is plausible to assume that the incorporation of larger $\mathrm{Ag}^{+}$cations into smaller $\mathrm{Ca}^{2+}$ sites can lead to an expansion in the lattice parameters [20] causing a larger anion-anion separation, as observed in this study. Nevertheless, this assumption by itself just considers that the ion sizes would not be sufficient to understand the incorporation mechanism since the charge of the incorporated ions and the strength of the corresponding established bonds should also play an important role in determining energetically preferable sites, particularly when monovalent cation, such as $\mathrm{Ag}^{+}$, incorporation takes place. For instance, even though the incorporation of divalent cations is not supposed to cause any charge imbalance in the HA lattice, incorporation of monovalent cations, such as $\mathrm{Ag}^{+}$, can cause an overall charge imbalance that can be neutralized simply by vacancy formation [39], or complex multi-ion incorporation with a combination of various cations and anions preserving an overall charge balance with or without additional vacancy formation [40].

In this regard, the absence of peaks for $\mathrm{OH}^{-}$groups in the FTIR spectra of AgHAs can suggest that monovalent $\mathrm{Ag}^{+}$ions were incorporated into the divalent $\mathrm{Ca}(1)$ positions coupled with the subsequent formation of an $\mathrm{OH}^{-}$vacancy to preserve the overall charge balance. $\mathrm{Ag}^{+}$ions can preferably be substituted, particularly into $\mathrm{Ca}(1)$ sites, because not only are $\mathrm{Ag}^{+}$ions larger, but also these sites have coordination with $\mathrm{OH}^{-}$with a relatively weaker bond and therefore the formation of this defect couple may be energetically more favorable [33]. Thereby, weaker $\mathrm{P}-\mathrm{O}$ stretching bands seem to be observed in the AgHA samples with an increase in $\mathrm{Ag}$ content (Figure 3) due to the subsequent increase in anionanion separation [41].

With this in regard, the following substitution model for the Ca deficient samples can be proposed:

$$
\mathrm{Ca}_{10-x} \mathrm{Ag}_{\mathrm{x}}\left(\mathrm{PO}_{4}\right)_{6}(\mathrm{OH})_{2-\mathrm{x}}
$$

This model also verifies that a decrease in the $\mathrm{Ca} / \mathrm{P}$ atomic ratio will occur with increasing Ag content in the Ca-deficient AgHAs as a result of Ca depletion from the HA structure upon $\mathrm{Ag}^{+}$incorporation, which is in an agreement with the elemental analysis given in Table 2.

Similarly, weaker FTIR peaks of $\mathrm{OH}^{-}$groups in P2 and P5 compared to those in pure $\mathrm{HA}$ can also suggest the incorporation of $\mathrm{Ag}^{+}$ions presumable into $\mathrm{Ca}(1)$ sites associated with possible $\mathrm{OH}^{-}$vacancy formations. Moreover, the observation of FTIR peaks belonging to B-type carbonate suggests a possible $\mathrm{CO}_{3}{ }^{2-}$ incorporation into $\mathrm{PO}_{4}{ }^{3-}$ sites as well. It should also be observed that an additional decrease in the amount of $\mathrm{PO}_{4}{ }^{3-}$ due to the possible $\mathrm{CO}_{3}{ }^{2-}$ anion incorporation will contribute further to the weakening of $\mathrm{P}-\mathrm{O}$ stretching bands in the $\mathrm{P}$ deficient samples.

Normally, monovalent anions can be expected to incorporate directly into $\mathrm{OH}^{-}$ positions in the anion channel without causing any charge imbalance. However, divalent anion incorporation of $\mathrm{CO}_{3}{ }^{2-}$ can be balanced by the formation of both $\mathrm{OH}^{-}$and $\mathrm{Ca}^{2+}$ 
vacancies instead of their direct incorporation into the trivalent $\mathrm{PO}_{4}{ }^{3-}$ positions [42]. Moreover, the charge imbalance induced by the incorporation of $\mathrm{CO}_{3}{ }^{2-}$ anions into $\mathrm{PO}_{4}{ }^{3-}$ sites can also be compensated by oxygen vacancies [43].

Based on these assumptions, the substitution model for the P-deficient AgHAs can be proposed as:

$$
\mathrm{Ca}_{10-\mathrm{x}} \mathrm{Ag}_{\mathrm{x}}\left\{\left(\mathrm{PO}_{4}\right)_{6-\mathrm{y}}\left(\mathrm{CO}_{3}\right)_{\mathrm{y}}\right\}(\mathrm{OH})_{2-\mathrm{f}(\mathrm{x}, \mathrm{y})}
$$

The respective illustrations of the proposed models for both $\mathrm{Ca}$ - and P-deficient AgHAs are also given in Figure 8, representing $\mathrm{Ag}^{+}$located in the $\mathrm{Ca}^{2+}$ position while $\mathrm{CO}_{3}{ }^{2-}$ is located in the $\mathrm{PO}_{4}{ }^{3-}$ position specifically in the case of P-deficient AgHA.

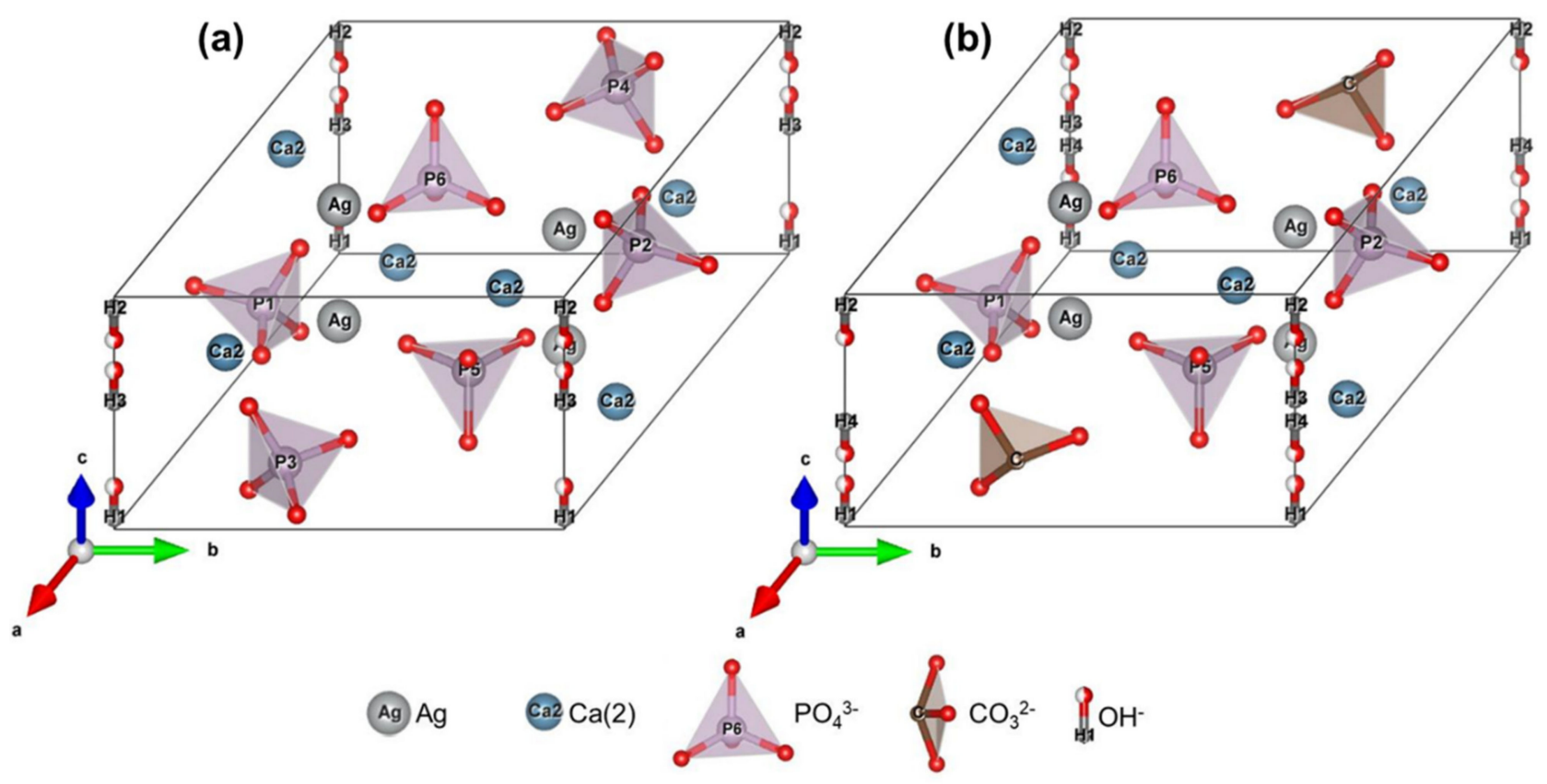

Figure 8. Representations of AgHA structure models synthesized with (a) Ca-deficient and (b) P-deficient precursors.

Moreover, it is plausible to expect an increasing $\mathrm{P}$ depletion due to $\mathrm{CO}_{3}{ }^{2-}$ incorporation into the $\mathrm{PO}_{4}{ }^{3-}$ sites contributing to an increase in the $\mathrm{Ca} / \mathrm{P}$ atomic ratio and also to an increase $\mathrm{Ca}$ depletion due to possible $\mathrm{Ag}^{+}$incorporation into $\mathrm{Ca}^{2+}$ sites contributing to a decrease in $\mathrm{Ca} / \mathrm{P}$ atomic ratio with increasing $\mathrm{Ag}$ content in the $\mathrm{HA}$ structure specifically in the P-deficient AgHAs. EDS analysis (Table 2) verified that there is an overall increase in the $\mathrm{Ca} / \mathrm{P}$ atomic ratio with an increase in the $\mathrm{Ag}$ content suggesting that $\mathrm{P}$ depletion has a dominant effect on the $\mathrm{Ca} / \mathrm{P}$ atomic ratio in the P-deficient AgHAs.

It was reported that an increase in sinterability was observed in $\mathrm{HA}$ upon $\mathrm{CO}_{3}{ }^{2-}$ incorporation particularly into the $\mathrm{PO}_{4}{ }^{3-}$ sites, which was called B-type carbonated HAs [44,45]. In this respect, the shift in the sintering temperatures into lower temperature regions observed in the P-deficient AgHAs compared to the Ca-deficient ones indicates better sinterability which seems to be due to carbonations in the structure.

\subsection{The Effect of Variations in the AgHA Structure on In Vitro Behavior}

Normally, increasing $\mathrm{Ag}$ content in AgHA would increase the antibacterial properties and the toxicity provided by a higher amount of Ag released at a given time. This statement was proven by Rameshbabu et al. [46] with an increase in the amount of Ag exhibiting significant antibacterial activity, however, it also inhibited cell growth. Contrarily, the results in this study clearly showed that the Ag content itself is not the only factor causing differences in antibacterial properties and osteoblast adhesion between the Ca-deficient and the P-deficient AgHAs. Indeed, it seems that structural differences specifically based 
on the types of structural defects (including the substitutional and interstitial ions as well as associated vacancies) occurred by the facilitation of the differences between the precursor preparation approaches is likely to be a crucial determining factor. Ma et al. reported that carbonated HA synthesized by a co-precipitation method with selenite incorporation using a P-precursor deficient solution precipitation method [33] can be a good choice for improved bone tissue engineering. For instance, facilitated by the introduced weaker $\mathrm{Ca}-\mathrm{CO}_{3}$ bonds partially replaced with relatively stronger $\mathrm{Ca}-\mathrm{PO}_{4}$ bonds, the solubility of carbonated HAs can increase [47]. Therefore, it is quite reasonable to expect higher dissolution rates in the P-deficient AgHAs specifically controlled by their carbonate contents than those synthesized from the Ca-deficient precursors. Additionally, the decreased crystallinity of the AgHA samples, as indicated by their broader XRD peaks, should inherently contribute to their dissolution rate compared to pure HA with better crystallinity [47].

Expectedly, C5 showed a higher bactericidal ratio than C2 because of its higher Ag content. In contrast, P5 with higher Ag content unexpectedly had a lower bactericidal ratio than P2. Taking its higher carbonate content into account, it is plausible to expect that P5 should have the highest dissolution rate among the AgHAs. Subsequently, the amount of $\mathrm{Ag}^{+}$ions in the NB solutions should be the greatest dissolved from P5 compared to that of the others tested, and therefore it is expected to have better bactericidal ratios than both P2 and C2. In contrast to this expectation, it presented the lowest value. In fact, the released $\mathrm{Ag}$ ions from $\mathrm{AgHAs}$ can be removed from the solution by $\mathrm{AgCl}$ precipitation as a result of a reaction between the released $\mathrm{Ag}^{+}$and $\mathrm{Cl}^{-}$ions already existing in the NB solutions as reported in our previous studies $[13,15,48]$. It was also reported that the antibacterial properties of micro-size metallic Ag nanoparticles can remarkably decrease due to the formation of an $\mathrm{AgCl}$ layer on their surfaces as a result of a precipitation reaction since $\mathrm{AgCl}$ inherently does not have effective bactericidal properties [11,49], although Kim et al. reported the antibacterial effect of $\mathrm{AgNO}_{3}$ in spite of $\mathrm{AgCl}$ precipitation [50], thus, raising the question of the importance of $\mathrm{AgCl}$ size. Another mechanism that prevents the effectiveness of P5 against bacteria might be the high-rate of $\mathrm{Ca}$ and P ion dissolution into the bacteria solution, which was expected to reprecipitate as a CaP phase while consuming released $\mathrm{Ag}^{+}$ions from the bacteria solution. On the other hand, Singh et al. observed suppressed $\mathrm{Ag}^{+}$ion release from HA with the presence of a TCP phase [27]. The delayed dissolution mechanism of TCP with Ag incorporation was previously reported [13]. According to these reports, it was assumed that Ca-deficient HA was insufficient to release $\mathrm{Ag}^{+}$ions compared to P-deficient HA.

Therefore, it is quite reasonable to assume that a faster release of Ag ions from P5 facilitated by its higher dissolution rate and fast removal of these highly antibacterial ions by the formation of relatively passive $\mathrm{AgCl}$ precipitates in the $\mathrm{NB}$ solutions, seems to considerably decrease its antibacterial properties [15]. In contrast, the reason for the interestingly better antibacterial properties of P2, even better than C2, despite lower Ag content should also be related to its relatively higher dissolution rate than $\mathrm{C} 2$ due to carbonated AgHA formation. However, its dissolution rate is expected to be relatively lower than that of P5 owing to its lower carbonate content.

In this respect, the time-dependent interaction between $\mathrm{Ag}^{+}$ions and the bacteria in the NB solution seems to be the controlling mechanism for the success of the bactericidal response in AgHAs. If there would be no sufficient time available for the $\mathrm{Ag}^{+}$ions to interact with the bacteria in the NB solution before its removal via the $\mathrm{AgCl}$ precipitation, the bactericidal properties can significantly diminish.

Similarly, the lower osteoblast adhesion observed on P2 and P5 even with their lower Ag content compared to their counterparts C2 and C5 seems to be also closely related to their carbonate content and a corresponding increase in dissolution behavior. The increasing dissolution rate of these samples seems to cause an increasing amount of Ag ions released into the testing environment and subsequently showed an increased toxic effect on the osteoblasts. Since P5 had the highest carbonate content, it should have the highest dissolution rate releasing the highest amount of $\mathrm{Ag}$ ions / $\mathrm{AgCl}$ precipitation, and 
therefore it showed the highest toxicity among the samples, in which $\mathrm{AgCl}$ would prevent cell adhesion due to its effective contact killing properties [13,15].

The present study verified that optimally preventing E. coli colonization and assuring sufficient osteoblast adhesion without the use of pharmaceutical drugs, such as antibiotics, which are contributing to the generation of antibiotic-resistant bacteria, can be achieved through Ag incorporated HA. It further demonstrated that in particular P deficiency in the precursor solution, seems to energetically favor the incorporation of $\mathrm{CO}_{3}{ }^{2-}$ anions into $\mathrm{PO}_{4}{ }^{3-}$ sites during the synthesis of AgHAs. Eventually, the amount of Ag content at a given time in both of the in vitro test media (specifically, the bacteria and osteoblast media) would mainly be determined by the complicated interaction between the amount of $\mathrm{Ag}$ in the sample itself and its dissolution controlled by carbonate content in a particular AgHA, in which P2 samples exhibited the best in vitro performance in this study. If these two parameters can be optimized, the carbonated AgHAs even with a lower Ag content can introduce better bactericidal properties compared to those AgHAs without carbonate content.

Controlling the amount of incorporated $\mathrm{CO}_{3}{ }^{2-}$ ions provided by $\mathrm{P}$ deficiency in the precursor solution can be utilized as an engineering design tool for tailoring timedependent antibacterial and osteoblast adhesion properties of the synthesized AgHAs for a specific application.

\section{Conclusions}

This study investigated Ag-incorporated HA synthesized from two different precursor solutions in terms of material characterization and in vitro cellular behavior: (a) a Cadeficient solution with a corresponding ratio of Ca-ions counterbalanced with $\mathrm{Ag}$ ions at a stoichiometric value of 1.67 obtained via the $(\mathrm{Ca}+\mathrm{Ag}) / \mathrm{P}$ atomic ratio, (b) a P-deficient solution with a corresponding ratio of $\mathrm{P}$-ions counterbalanced with $\mathrm{Ag}^{+}$ions also at a stoichiometric value of 1.67 obtained via the $\mathrm{Ca} /(\mathrm{P}+\mathrm{Ag})$ atomic ratio, and (c) one with an extra $0.2 \mathrm{~mol} \mathrm{Ag}$ added without any compensation in either Ca or P. The results were compared to those of pure HA in terms of material characterization, antibacterial behavior with E. coli, and in vitro osteoblast adhesion. The following conclusions can be drawn from the results of this investigation:

1. A higher amount of $\mathrm{Ag}$ incorporation was accomplished in the precipitation method when using Ca- or P-deficient precursors compared to extra Ag addition into the precursor. Nevertheless, the highest amount of Ag content was obtained when using Ca-deficient precursors.

2. Ag incorporation occurred into $\mathrm{Ca}(1)$ sites associated with an $\mathrm{OH}^{-}$vacancy in both $\mathrm{Ca}$ - and P-deficient AgHAs. Additional incorporation of $\mathrm{CO}_{3}{ }^{2-}$ ions into $\mathrm{PO}_{4}{ }^{3-}$ sites occurred in the P-deficient AgHAs.

3. Densification started at lower temperatures in the P-deficient AgHA than those of the Ca-deficient ones owing to its carbonated structure.

4. As the Ag content increased in the Ca-deficient AgHAs, the bactericidal properties increased, while osteoblast adhesion decreased.

5. P-deficient AgHAs, even with lower Ag content, exhibited a better combination of bactericidal properties and osteoblast adhesion behavior. On the other hand, both properties substantially diminished as the Ag content increased.

This investigation demonstrated for the first time in the literature that particularly $\mathrm{P}$ deficiencies in the precursor solution seemed to energetically favor the incorporation of the $\mathrm{CO}_{3}{ }^{2-}$ anion into $\mathrm{PO}_{4}{ }^{3-}$ sites. Eventually, the amount of $\mathrm{CO}_{3}{ }^{2-}$ ion incorporation controlled by $\mathrm{P}$ deficiency can be utilized as a design tool for engineering properties of the synthesized AgHAs for specific applications. Although requiring more investigation, these results indicated that P-deficient AgHA has a great potential as an alternative for bone regeneration with antibacterial properties without resorting to harmful antibiotic use. 
Author Contributions: Conceptualization, O.G. and C.E.; methodology, T.J.W. and A.B.; software, O.G.; validation, O.G., C.E., and T.J.W.; formal analysis, O.G., A.B., and T.J.W.; investigation, O.G., A.B., and T.J.W.; resources, C.E. and T.N. (Takayuki Narushima); data curation, O.G.; writingoriginal draft preparation, O.G. and C.E.; writing-review and editing, C.E., T.J.W., K.U., T.N. (Takayuki Narushima), and T.N. (Takayoshi Nakano); visualization, O.G.; supervision, C.E.; project administration, C.E. and T.N. (Takayuki Narushima); funding acquisition, C.E. and T.N. (Takayuki Narushima). All authors have read and agreed to the published version of the manuscript.

Funding: This research was financially supported by the Scientific and Technological Research Council of Turkey (TUBITAK Contract No: 106M053) and the Japan Society for the Promotion of Science (Contract No: 201500660).

Institutional Review Board Statement: Not applicable.

Informed Consent Statement: Not applicable.

Data Availability Statement: No new data were created or analyzed in this study.

Conflicts of Interest: The authors declare no conflict of interest.

\section{References}

1. Elliott, J.C. Structure and Chemistry of the Apatites and Other Calcium Orthophosphates; Studies in Inorganic Chemistry; Elsevier: Amsterdam, The Netherlands, 2013; ISBN 9781483290317.

2. Hench, L.L. Bioceramics. J. Am. Ceram. Soc. 1998, 81, 1705-1728. [CrossRef]

3. Hall-Stoodley, L.; Costerton, J.W.; Stoodley, P. Bacterial biofilms: From the Natural environment to infectious diseases. Nat. Rev. Microbiol. 2004, 2, 95-108. [CrossRef]

4. Steckelberg, J.M.; Osmon, D.R. Prosthetic Joint Infections. Infect. Assoc. Indwelling Med. Devices 2000, 9, $173-209$.

5. Mack, D.; Rohde, H.; Harris, L.G.; Davies, A.P.; Horstkotte, M.A.; Knobloch, J.K.-M. Biofilm Formation in Medical Device-Related Infection. Int. J. Artif. Organs 2006, 29, 343-359. [CrossRef] [PubMed]

6. Liu, X.; Mou, Y.; Wu, S.; Man, H.C. Synthesis of silver-incorporated hydroxyapatite nanocomposites for antimicrobial implant coatings. Appl. Surf. Sci. 2013, 273, 748-757. [CrossRef]

7. Ueno, M.; Miyamoto, H.; Tsukamoto, M.; Eto, S.; Noda, I.; Shobuike, T.; Kobatake, T.; Sonohata, M.; Mawatari, M. Silvercontaining hydroxyapatite coating reduces biofilm formation by Methicillin-Resistant Staphylococcus aureus in vitro and in vivo. Biomed. Res. Int. 2016, 2016, 8070597. [CrossRef]

8. Sahni, G.; Gopinath, P.; Jeevanandam, P. A novel thermal decomposition approach to synthesize hydroxyapatite-silver nanocomposites and their antibacterial action against GFP-expressing antibiotic resistant E. coli. Colloids Surf. B Biointerfaces 2013, 103, 441-447. [CrossRef]

9. Cao, H.; Qiao, Y.; Liu, X.; Lu, T.; Cui, T.; Meng, F.; Chu, P.K. Electron storage mediated dark antibacterial action of bound silver nanoparticles: Smaller is not always better. Acta Biomater. 2013, 9, 5100-5110. [CrossRef] [PubMed]

10. Darouiche, R.O. Anti-infective efficacy of silver-coated medical prostheses. Clin. Infect. Dis. Off. Publ. Infect. Dis. Soc. Am. 1999, 29, 1371-1377. [CrossRef]

11. Mokabber, T.; Cao, H.T.; Norouzi, N.; van Rijn, P.; Pei, Y.T. Antimicrobial electrodeposited silver-containing calcium phosphate coatings. ACS Appl. Mater. Interfaces 2020, 12, 5531-5541. [CrossRef]

12. Šupová, M. Substituted hydroxyapatites for biomedical applications: A review. Ceram. Int. 2015, 41, 9203-9231. [CrossRef]

13. Gokcekaya, O.; Ueda, K.; Ogasawara, K.; Kanetaka, H.; Narushima, T. In vitro evaluation of Ag-containing calcium phosphates: Effectiveness of Ag-incorporated $\beta$-tricalcium phosphate. Mater. Sci. Eng. C 2017, 75, 926-933. [CrossRef]

14. Stanić, V.; Dimitrijević, S.; Antić-Stanković, J.; Mitrić, M.; Jokić, B.; Plećaš, I.B.; Raičević, S. Synthesis, characterization and antimicrobial activity of copper and zinc-doped hydroxyapatite nanopowders. Appl. Surf. Sci. 2010, 256, 6083-6089. [CrossRef]

15. Gokcekaya, O.; Ueda, K.; Ogasawara, K.; Narushima, T. Antibacterial activity of Ag nanoparticle-containing hydroxyapatite powders in simulated body fluids with $\mathrm{Cl}$ ions. Mater. Chem. Phys. 2019, 223, 473-478.

16. Ueda, T.; Kondo, N.; Sado, S.; Gokcekaya, O.; Ueda, K.; Ogasawara, K.; Narushima, T. Ceramic coating of Ti and its alloys using dry processes for biomedical applications. In Interface Oral Health Science 2016; Sasaki, K., Suzuki, O., Takahashi, N., Eds.; Springer: Singapore, 2017; pp. 23-34.

17. Barros, J.A.R.; de Melo, L.D.R.; da Silva, R.A.R.; Ferraz, M.P.; de Rodrigues Azeredo, J.C.V.; de Carvalho Pinheiro, V.M.; Colaço, B.J.A.; Fernandes, M.H.R.; de Sousa Gomes, P.; Monteiro, F.J. Encapsulated bacteriophages in alginate-nanohydroxyapatite hydrogel as a novel delivery system to prevent orthopedic implant-associated infections. Nanomed. Nanotechnol. Biol. Med. 2020, 24, 102145. [CrossRef] [PubMed]

18. Prabhu, S.; Poulose, E. Silver nanoparticles: Mechanism of antimicrobial action, synthesis, medical applications, and toxicity effects. Int. Nano Lett. 2012, 2, 1-10. [CrossRef]

19. Ishikawa, K.; Garskaite, E.; Kareiva, A. Sol-gel synthesis of calcium phosphate-based biomaterials-A review of environmentally benign, simple, and effective synthesis routes. J. Sol-Gel Sci. Technol. 2020, 94, 551-572. [CrossRef] 
20. Gokcekaya, O.; Ueda, K.; Narushima, T.; Ergun, C. Synthesis and characterization of Ag-containing calcium phosphates with various Ca/P ratios. Mater. Sci. Eng. C 2015, 53, 111-119. [CrossRef] [PubMed]

21. Barheine, S.; Hayakawa, S.; Jäger, C.; Shirosaki, Y.; Osaka, A. Effect of Disordered Structure of Boron-Containing Calcium Phosphates on their In Vitro Biodegradability. J. Am. Ceram. Soc. 2011, 94, 2656-2662. [CrossRef]

22. Sayahi, M.; Santos, J.; El-Feki, H.; Charvillat, C.; Bosc, F.; Karacan, I.; Milthorpe, B.; Drouet, C. Brushite $\left(\mathrm{Ca}_{1} \mathrm{M}\right) \mathrm{HPO}_{4}, 2 \mathrm{H}_{2} \mathrm{O}$ doping with bioactive ions $\left(\mathrm{M}=\mathrm{Mg}^{2+}, \mathrm{Sr}^{2+}, \mathrm{Zn}^{2+}, \mathrm{Cu}^{2+}\right.$, and $\left.\mathrm{Ag}^{+}\right)$: A new path to functional biomaterials? Mater. Today Chem. 2020, 16, 100230. [CrossRef]

23. Kamonwannasit, S.; Futalan, C.M.; Khemthong, P.; Butburee, T.; Karaphun, A.; Phatai, P. Synthesis of copper-silver doped hydroxyapatite via ultrasonic coupled sol-gel techniques: Structural and antibacterial studies. J. Sol-Gel Sci. Technol. 2020, 96, 452-463. [CrossRef]

24. Arcos, D.; Vallet-Regí, M. Substituted hydroxyapatite coatings of bone implants. J. Mater. Chem. B 2020, 8, 1781-1800. [CrossRef] [PubMed]

25. Jacobs, A.; Gaulier, M.; Duval, A.; Renaudin, G. Silver Doping Mechanism in Bioceramics-From $\mathrm{Ag}^{+}:$Doped $\mathrm{HAp}_{\text {to }} \mathrm{Ag}^{\circ} / \mathrm{BCP}$ Nanocomposite. Crystals 2019, 9, 326. [CrossRef]

26. Gokcekaya, O.; Ueda, K.; Narushima, T.; Nakano, T. Using HAADF-STEM for atomic-scale evaluation of incorporation of antibacterial Ag atoms in a $\beta$-tricalcium phosphate structure. Nanoscale 2020, 12, 16596-16604. [CrossRef] [PubMed]

27. Singh, B.; Dubey, A.K.; Kumar, S.; Saha, N.; Basu, B.; Gupta, R. In vitro biocompatibility and antimicrobial activity of wet chemically prepared $\mathrm{Ca}_{10-\mathrm{x}} \mathrm{Ag}_{\mathrm{x}}\left(\mathrm{PO}_{4}\right)_{6}(\mathrm{OH})_{2}(0.0 \leq \mathrm{x} \leq 0.5)$ hydroxyapatites. Mater. Sci. Eng. C 2011, 31, 1320-1329. [CrossRef]

28. Ergun, C.; Webster, T.J.; Bizios, R.; Doremus, R.H. Hydroxylapatite with substituted magnesium, zinc, cadmium, and yttrium. I. Structure and microstructure. J. Biomed. Mater. Res. 2002, 59, 305-311. [CrossRef] [PubMed]

29. Gokcekaya, O.; Ueda, K.; Narushima, T.; Ergun, C. Preparation of Ag-doped calcium phosphates. In 8th Pacific Rim International Congress on Advanced Materials and Processing 2013; PRICM 8; Springer: Berlin, Germany, 2013; Volume 2.

30. Momma, K.; Izumi, F. VESTA 3 for three-dimensional visualization of crystal, volumetric and morphology data. J. Appl. Crystallogr. 2011, 44, 1272-1276. [CrossRef]

31. Ergun, C. Effect of Ti ion substitution on the structure of hydroxylapatite. J. Eur. Ceram. Soc. 2008, 28, 2137-2149. [CrossRef]

32. Webster, T.J.; Massa-Schlueter, E.A.; Smith, J.L.; Slamovich, E.B. Osteoblast response to hydroxyapatite doped with divalent and trivalent cations. Biomaterials 2004, 25, 2111-2121. [CrossRef]

33. Ma, J.; Wang, Y.; Zhou, L.; Zhang, S. Preparation and characterization of selenite substituted hydroxyapatite. Mater. Sci. Eng. C 2013, 33, 440-445. [CrossRef]

34. Fleet, M.E.; Liu, X. Coupled substitution of type A and B carbonate in sodium-bearing apatite. Biomaterials 2007, 28, 916-926. [CrossRef]

35. Ou, S.-F.; Chiou, S.-Y.; Ou, K.-L. Phase transformation on hydroxyapatite decomposition. Ceram. Int. 2013, 39, 3809-3816. [CrossRef]

36. Nakamura, S.; Otsuka, R.; Aoki, H.; Akao, M.; Miura, N.; Yamamoto, T. Thermal expansion of hydroxyapatite- $\beta$-tricalcium phosphate ceramics. Thermochim. Acta 1990, 165, 57-72. [CrossRef]

37. Gokcekaya, O.; Webster, T.J.; Ueda, K.; Narushima, T.; Ergun, C. In vitro performance of Ag-incorporated hydroxyapatite and its adhesive porous coatings deposited by electrostatic spraying. Mater. Sci. Eng. C 2017, 77, 556-564. [CrossRef]

38. Xu, Y.; Geng, Z.; Gao, Z.; Zhuo, X.; Li, B.; Cui, Z.; Zhu, S.; Liang, Y.; Li, Z.; Yang, X. Effects of both Sr and Mg substitution on compositions of biphasic calcium phosphate derived from hydrothermal method. Int. J. Appl. Ceram. Technol. 2018, 15, 210-222. [CrossRef]

39. Yoshida, K.; Hyuga, H.; Kondo, N.; Kita, H.; Sasaki, M.; Mitamura, M.; Hashimoto, K.; Toda, Y. Substitution model of monovalent ( $\mathrm{Li}, \mathrm{Na}$, and $\mathrm{K})$, divalent $(\mathrm{Mg})$, and trivalent (Al) metal ions for $\beta$-tricalcium phosphate. J. Am. Ceram. Soc. 2006, 89, 688-690. [CrossRef]

40. Kannan, S.; Goetz-Neunhoeffer, F.; Neubauer, J.; Pina, S.; Torres, P.M.C.; Ferreira, J.M.F. Synthesis and structural characterization of strontium- and magnesium-co-substituted $\beta$-tricalcium phosphate. Acta Biomater. 2010, 6, 571-576. [CrossRef] [PubMed]

41. Bigi, A.; Boanini, E.; Capuccini, C.; Gazzano, M. Strontium-substituted hydroxyapatite nanocrystals. Inorganica Chim. Acta 2007, 360, 1009-1016. [CrossRef]

42. Gomes, S.; Nedelec, J.-M.; Jallot, E.; Sheptyakov, D.; Renaudin, G. Silicon location in silicate-substituted calcium phosphate ceramics determined by neutron diffraction. Cryst. Growth Des. 2011, 11, 4017-4026. [CrossRef]

43. Tite, T.; Popa, A.-C.; Balescu, L.M.; Bogdan, I.M.; Pasuk, I.; Ferreira, J.M.F.; Stan, G.E. Cationic substitutions in hydroxyapatite: Current status of the derived biofunctional effects and their in vitro interrogation methods. Materials 2018, 11, 2081. [CrossRef] [PubMed]

44. Gibson, I.R.; Bonfield, W. Preparation and characterization of magnesium/carbonate co-substituted hydroxyapatites. J. Mater. Sci. Mater. Med. 2002, 13, 685-693. [CrossRef]

45. Landi, E.; Tampieri, A.; Celotti, G.; Vichi, L.; Sandri, M. Influence of synthesis and sintering parameters on the characteristics of carbonate apatite. Biomaterials 2004, 25, 1763-1770. [CrossRef] [PubMed]

46. Rameshbabu, N.; Sampath Kumar, T.S.; Prabhakar, T.G.; Sastry, V.S.; Murty, K.V.G.K.; Prasad Rao, K. Antibacterial nanosized silver substituted hydroxyapatite: Synthesis and characterization. J. Biomed. Mater. Res. A 2007, 80, 581-591. [CrossRef] [PubMed] 
47. Rogers, K.D.; Daniels, P. An X-ray diffraction study of the effects of heat treatment on bone mineral microstructure. Biomaterials 2002, 23, 2577-2585. [CrossRef]

48. Gokcekaya, O.; Ueda, K.; Narushima, T. Control of Ag release from Ag-containing calcium phosphates in simulated body fluid. Ceramic Trans. 2015, 254, 13-20.

49. Gokcekaya, O.; Ueda, K.; Narushima, T.; Ogasawara, K.; Kanetaka, H. In vitro properties of Ag-containing calcium phosphates. Proc. Ceram. Eng. Sci. Proc. 2017, 37, 87-93.

50. Kim, T.N.; Feng, Q.L.; Kim, J.O.; Wu, J.; Wang, H.; Chen, G.C.; Cui, F.Z. Antimicrobial effects of metal ions $\left(\mathrm{Ag}^{+}, \mathrm{Cu}^{2+}, \mathrm{Zn}^{2+}\right)$ in hydroxyapatite. J. Mater. Sci. Mater. Med. 1998, 9, 129-134. [CrossRef] [PubMed] 